\title{
Short-Selling Restrictions and Returns: a Natural Experiment
}

\author{
Marco Bonomo * João M. P. De Mello $^{*} \quad$ Lira Mota $^{\dagger}$ \\ Sunday $15^{\text {th }}$ February, 2015
}

\begin{abstract}
Restrictions on short-selling may impede market participants from fully expressing their opinions about an asset, causing departures from price efficiency (Miller (1977)). Measuring the impact of short-selling restriction on returns has been elusive because the decision to sell short reflects expectations on returns. We measure the causal impact of short-selling restrictions on returns by taking advantage of an unique dataset and an unique source of exogenous variation in rental fees. In Brazil during the 2010 - 2013 period rental transaction from individual investors to mutual funds carried an implicit tax discount on days of distribution of Interest on Net Equity (IoNE). The possibility of tax arbitrage produces an exogenous spike in rental fees and short interest during the days surrounding IoNE distribution, making it prohibitively expensive to short-sell for speculative reasons. Our data con-

\footnotetext{
${ }^{*}$ Insper - SP

${ }^{\dagger}$ EPGE-FGV/Rio
} 
tains all rental transaction and the identity of the parts, thus allowing us identify transactions for tax arbitrage. We find that the variation of rental fees induced by the tax arbitrage operations has a large impact on abnormal returns, corroborating Miller's hypothesis.

JEL classification: G12, G14. 


\section{Introduction}

Since the seminal article of Miller (1977), the impact of short-selling constraints on financial markets have been subject of numerous theoretical and empirical studies. One of the most widely predicted effect, is that the interaction between heterogeneous valuations and short-sale constraint would lead to prices superior to the average valuation. Thus, both an increase in heterogeneity or in short-sale constraints would pressure prices upwards. While several empirical papers have convincingly illustrated (both cross-sectional and temporal) the effect of variation in heterogeneity, documenting the effect of variation of short-selling constraints pose a greater challenge.

Identification of the causal impact of short-selling restrictions on returns has been elusive for two reasons: data availability and the endogeneity of the decision to sell short. Many studies have empirically tested the proposed models, but they all had to deal with the problem of limited data availability (see, e.g., Cohen, Diether, and Malloy (2007), Saffi and Sigurdsson (2011)). In most financial markets, lending services are provided over the counter by big custodian banks, and there is no institution that centralizes the registration of the loan contracts. This makes data aggregation virtually impossible, and many times jeopardizes the reliability of the results. Perhaps more importantly, the decision to short sell is not random. Thus, variations in both rental fees and short interest contain changes in investors' (unobserved) expectations about returns, reducing its usefulness for causal inference.

In this paper we make use of an unique dataset and an unique source of exogenous variation in rental fees and short interest in order to measure the causal impact on short-selling restrictions on returns. In Brazil, during the 2010-2013 period there were large spikes in rental activities on days surrounding the distribution of Interest on Net Equity (IoNE), due to a tax arbitrage operation involving equity loans from individual investors to mutual funds. This intensive rental activity caused by tax arbitrage opportunities restricted the supply of loans on those days. Thus, they provide a quasi-natural ex- 
periment of exogenous variation in availability of equity loans for speculative trades in the spot market. Our result show that the increased short-selling restrictions on days of distribution of IoNE cause an increase in the stock price, corroborating the effect predicted by Miller (1977).

The Brazilian security lending market provides an unique opportunity to circumvent the difficulties with data and identification. In Brazil the rental market take place in a centralized platform in the only stock exchange presently operating in Brazil - the BM\&FBovespa. Thus, we observe all rental transactions, which mitigates possible biases due to selective data availability. We also observe the type of investor transacting, which allows us to distinguish between rental transactions motivated by tax arbitrage and for speculative trades in the spot market.

We take advantage of a natural experiment provided the opportunity to avoid income taxation. Brazilian companies normally distribute Interest on Net Equity (IoNE) up to the legally allowed limit. IoNE is equivalent to interest, and subject to the 15-percent tax rate on interest income. However, domestic mutual funds are exempted from taxation on IoNE. If an individual investor lends a stock to a mutual fund during the payment of IoNE, the mutual fund will return the stock plus the IoNE payment net of taxes. Since the fund is exempt, it keeps the equivalent amount of tax. The tax savings on these operations are normally split between the lender and the borrowers through a large increase in lending fees. This large contraction in lending supply manifests itself in large fee increases. The mean lending fee in rental transactions jumps fivefold, from an average of $2.3 \%$ of the notional value in normal periods to $11.5 \%$ in periods of IoNE distribution. The short interest jumps from $1.3 \%$ to $3.5 \%$.

The supply shock can be tantamount to a short-selling restriction because it could make short-selling for speculative reasons all but unprofitable. This is the first part of our empirical strategy. We use daily variation to associate the event of IoNE distribution to abnormal returns, a reduced-form object. 
We find that in a typical two-week event window around the distribution of IoNE, the stock experience an average of 74 bps abnormal return.

The mean increase in fees is very large, but there is considerable variation in the supply shock across events. Because we observe the identity of the parties in the transaction, we can compute the increase in fees across transaction between mutual funds, which are not driven by tax arbitrage. We call this increase in fees the non-arbitrage increase in fees. Thus, we have a direct quantitative measure of the size of the supply shock for each event. We associate this direct measure of the magnitude of the supply shock to abnormal returns. We do not associate abnormal returns to all the variation in the increase in lending fees in non-arbitrage transactions because variations in those fees could also reflect changes in demand for loans for speculative reasons. We use only variation in the increase in fees in non-arbitrage transactions that is explained by the increase in fees and by the short-interest in arbitrage transactions. In summary, we estimate the causal impact of lending fees on returns, a pure Miller hypothesis effect.

Why is this a legitimate source of exogenous variation? On average across events, both the short-interest and the lending fees in arbitrage transactions increase sharply because of the tax arbitrage opportunity. But we go farther and explore the fact that in some cases the spike is stronger than in others cases. As expected, the amount of IoNE determines the increase in lending fees and the amount of short-interest in arbitrage transactions. If the amount of IoNE contains information about the value of the firm, then the instruments would not be valid. Companies distribute IoNE up to the legal limit because it entails a 15-percent tax rate instead of rate that is almost always higher than $15 \% \square$. Thus, in practice the IoNE is determined deterministically by the amount of earnings, which is announced earlier, outside our window of analysis. In summary, the high frequency of the data helps

\footnotetext{
${ }^{1}$ For the companies in our sample, the corporate tax rate is $15 \%$ plus $10 \%$ multiplied by the difference between annual earnings and $\mathrm{R} \$ 240,000$ (or $\mathrm{U} \$ 95,000$ ), which amounts to a corporate tax rate of almost $25 \%$.
} 
identification.

The empirical literature has dealt with the problem of the endogeneity of short-selling restrictions with varying degrees of success. Saffi and Sigurdsson (2011) explore a panel of stocks and associate lending supply and fees to several measures of price efficiency, such as bid-ask spreads. Their panel strategy with fixed-effects and a long time-series accounts for a large fraction of variation. However, it is not possible to guarantee that unobserved (to the econometrician) shocks are not driving simultaneously both returns (or bid-ask spreads) and fees or lending supply. In fact, results in earlier papers showed that short-interest predicted negative future abnormal returns, suggestive that it has informational content (Cohen et al. (2007); Figlewski (1981). This presents a challenge to any identification strategy that the relationship between equilibrium short-interest and returns as a measure of short-selling restrictions.

Boehmer, Jones, and Zhang (2013) explores the short-sale ban of 2008 of more than 1,000 stocks, and find no price bump for these stocks. Their identification strategy is matching banned stocks with similar stocks that never suffered the ban. Matching is an adequate procedure to account for observed heterogeneity, but the decision to ban short-selling of some particular stocks is not random. Arguably, regulators were particularly concerned about supporting the prices of those stocks. In this case, it may be that regulators had information - unavailable to the econometrician - and thus not captured in the matching procedure. Cohen et al. (2007) choose a different strategy. They postulate that increases in fees associated with increases in lending indicate a (net) increase in the demand for shorting. Increases in fees coupled with reductions in lending represent a supply shock. If supply shocks are due to institutional changes, their impact on returns would be a test of the Miller hypothesis. But this assumes implicitly that supply shocks do not themselves contain any information about the returns, which in many settings can be a strong assumption. 
Kaplan, Moskowitz, and Sensoy (2013) perform a field experiment, randomly increasing the supply of stocks available for lending by a particular money manager. They find almost no impact on outcome variables such as returns and bid-ask spreads. Experimental data provides convincing exogenous variation. But the size of the supply shock, large as the variation in relative supply of the money manager for these stocks, may be too small to produce a quantitatively relevant impact. Finally, De-Losso, Genaro, and Giovannetti (2013) explore the same Brazilian data that we do, associate supply shocks with overpricing. They define a supply shock the same way Cohen et al. (2007) do, with the advantage of observing the size of supply shock for each stock, not a qualitative indicator of an increase in fees coupled with a reduction in lending (the supply shock in Cohen et al. (2007)). Similarly to Cohen et al. (2007), this identification strategy works only if the decision to change the supply is driven solely by factors other than opinions on the stock value - a strong assumption.

We move one step forward relative to the empirical literature. We find a clear source of exogenous source of variation in lending fees (and in the supply of stocks for lending), which has two major advantages. First, we do not rely on assuming that non-observables are not systematically related to variation in lending fees, an implicit assumption in both Saffi and Sigurdsson (2011) and Boehmer et al. (2013). We also do not need to assume that supply shocks are not driven by expectations on the stock returns, an implicit assumption in Cohen et al. (2007) and De-Losso et al. (2013). We have much larger shocks than Kaplan et al. (2013), which may explain the difference between our results and theirs. Differently from citeKMS2013, Cohen et al. (2007) and De-Losso et al. (2013), we find an impact of short-selling restrictions on the most liquid stocks in the IBOVESPA index. This is a strong result because the literature suggests that short-selling restrictions have a weaker impact on liquid stocks Cohen et al. (2007). 


\section{Stock Loan Market in Brazil}

The Brazilian stock loan market has become increasingly important in the last ten years. In 2013 it achieved repeatedly records of traded volume, the first one in March, and the second in April, when it passed the landmark of $\mathrm{R} \$ 100$ billions.

As in most developed countries, the loan market in Brazil is mostly an over-the-counter (OTC) market, i.e., parties reach each other through a noncentralized market. Differently from other countries though, all loan contracts must be registered in the Brazilian stock exchange, BM\&FBovespa. BM\&FBovespa works as a central counterpart for the loan contracts and keeps track of the collateral of the contract.

Other than the OTC configuration, lenders may choose to use a system in which submitted offers are publicly displayed to all market participants and traded in transparent and centralized format. This type of trade represented roughly $1 \%$ of all loan trades from January 2007 to June 2013 2. In both cases, OTC or centralized, the offers and the contracts are registered in a centralized system managed by BM\&FBovespa. BM\&FBovespa consolidates than a complete dataset about the totality of the Brazilian loan market. This feature mitigates data aggregation problems encountered in many short selling studies and transforms Brazil in a unique case of study in the shortselling literature.

A typical lending operation involves the exchange and four different participants: the lender, the borrower, the lender's broker and the borrower's broker. The diagram bellow illustrates a typical loan contract:

\footnotetext{
${ }^{2}$ This is an estimate based on interviews with Brazilian brokers. We do not have a precise data.
} 


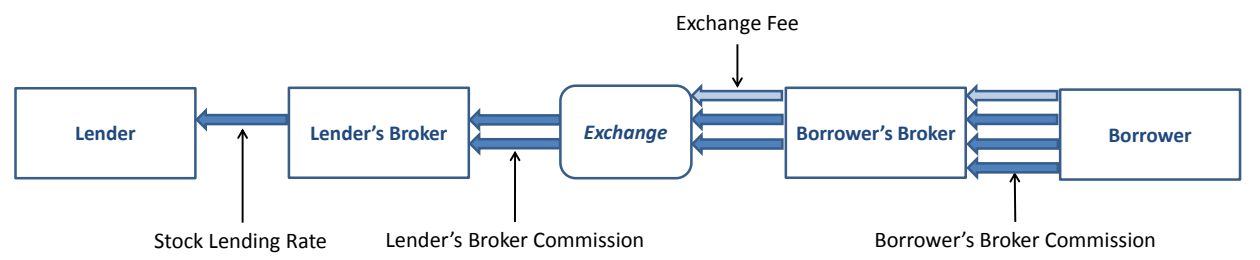

Figure 1. Loan market diagram: typical contract

The cost to borrow an stock is then the loan fee (which includes both brokers commission fees), plus an exchange fee of $0.25 \%$ annually.

To provide a general overview about the Brazilian loan market we present Table I. Between 2007 and 2013, the Brazilian lending market on average experienced an annual volume growth of $23.5 \%$, and a loan fee decrease of 43 basis points per year. Retail investors, domestic mutual funds and foreign investors add up to approximately $90 \%$ of in the lending side, while borrowers are mainly composed by domestic mutual funds (56.7\%) and foreign investors $(27,8 \%)$ - Figures 2 and 3 .

Table ISummary Statistics: Brazilian Equity Loan Market

\begin{tabular}{cccccc}
\hline \hline Year & Num. Stocks & Volume (BRL\$ bi) & Volume (US\$ bi) & Average Fee (\%) & Average Short-Interest (\%) \\
\hline 2007 & 323 & 272.473 & 142.106 & 5 & 0.611 \\
2008 & 313 & 303.505 & 174.568 & 3.655 & 0.540 \\
2009 & 323 & 258.912 & 137.483 & 2.850 & 0.365 \\
2010 & 346 & 465.605 & 265.892 & 2.990 & 0.427 \\
2011 & 353 & 732.750 & 436.302 & 2.842 & 0.675 \\
2012 & 330 & 785.927 & 405.854 & 2.252 & 0.849 \\
2013 (until June) & 294 & 500.269 & 246.665 & 2.148 & 1.236 \\
\hline
\end{tabular}




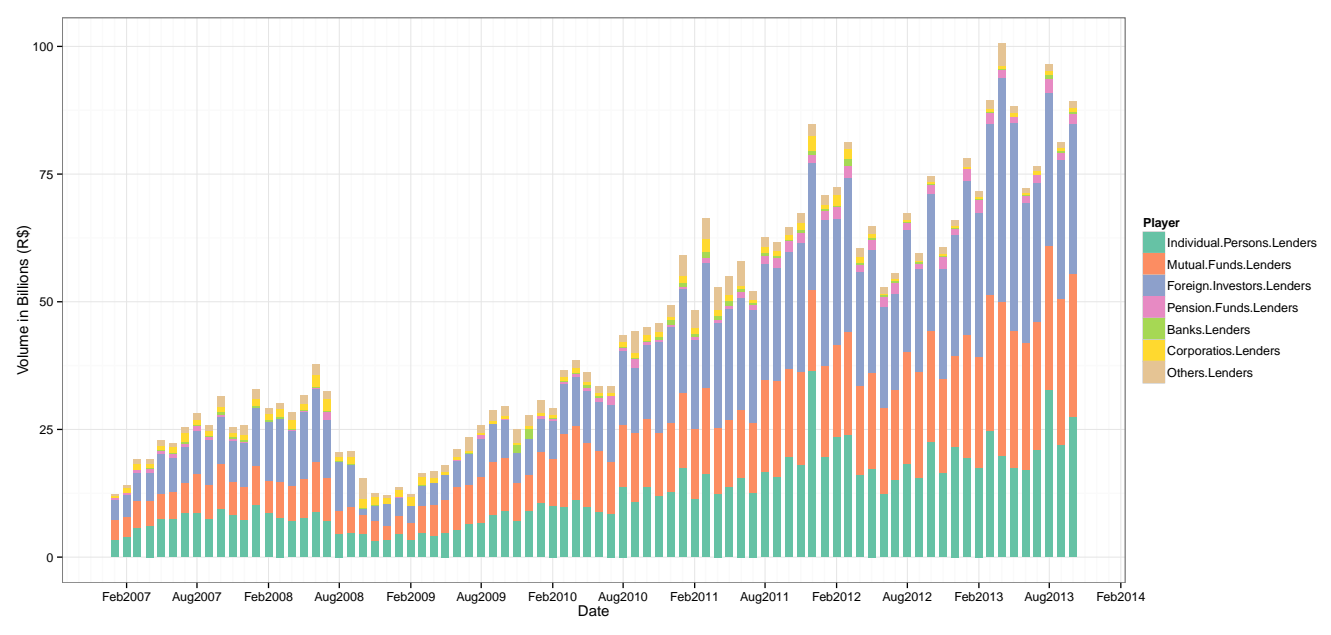

Figure 2. Loan Balance: Lenders.

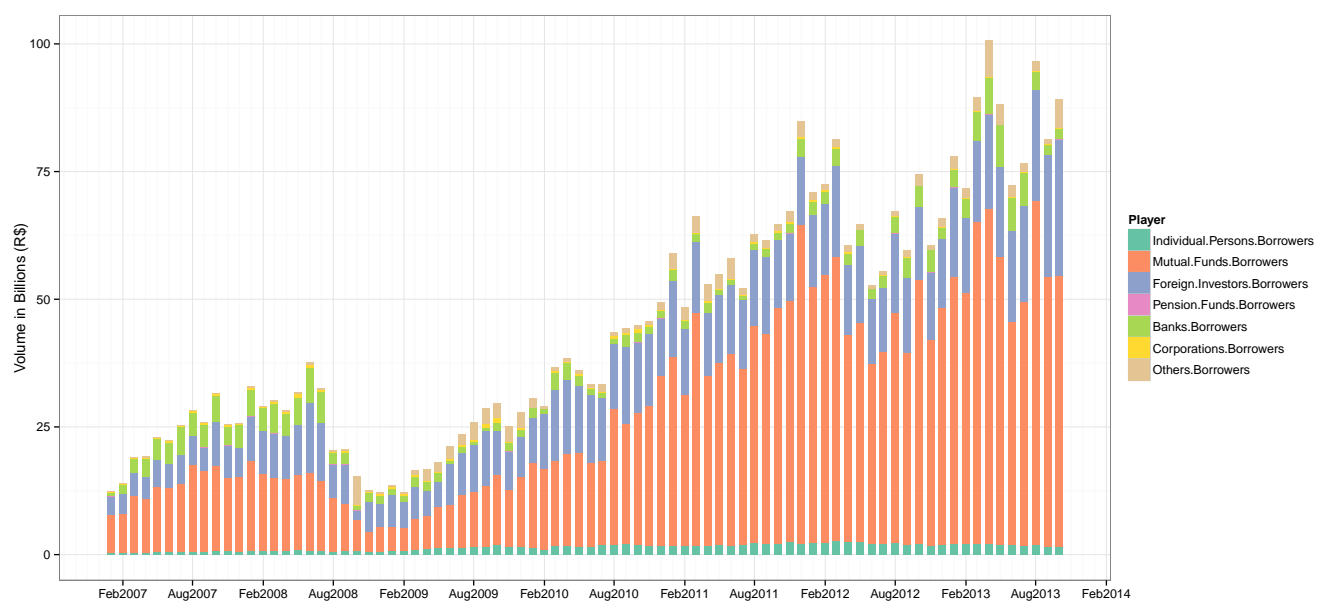

Figure 3. Loan Balance: Borrowers

The histogram presented in Figure 4 represents the distribution of the annual average loan fees for each stock between January 2007 and June 2013. The vertical axis shows the frequency of firms with average loan fees in the 
interval displayed in the horizontal axis. The figure shows that $87.82 \%$ of the Brazilian market is on average special $!^{3}$.

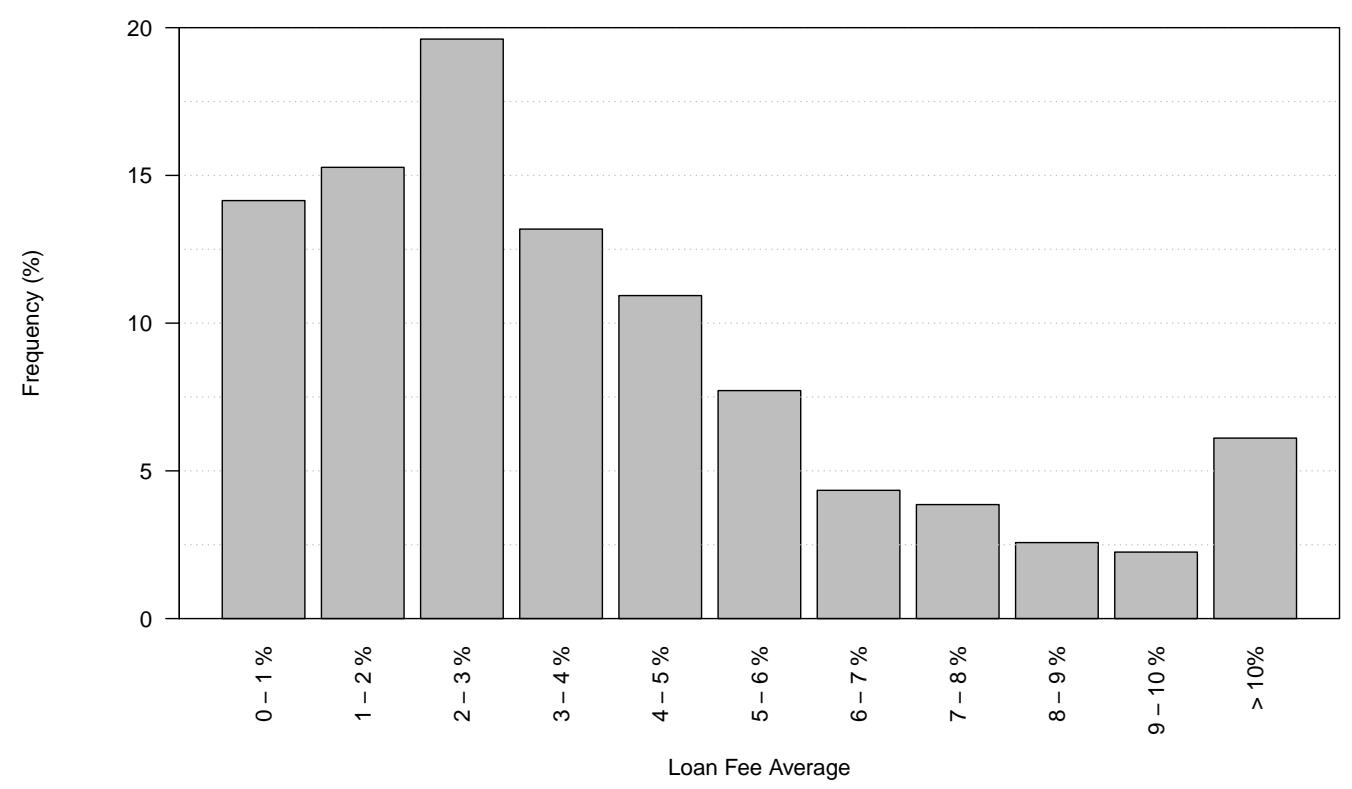

Figure 4. Distribution of Loan Fees By Firms: 2007-2013

Figures 5 and 6 illustrates the loan fee decrease in the recent years.

\footnotetext{
${ }^{3}$ We recall the reader that, in the financial jargon, a "special" stock is one with annual loan fee above $1 \%$
} 


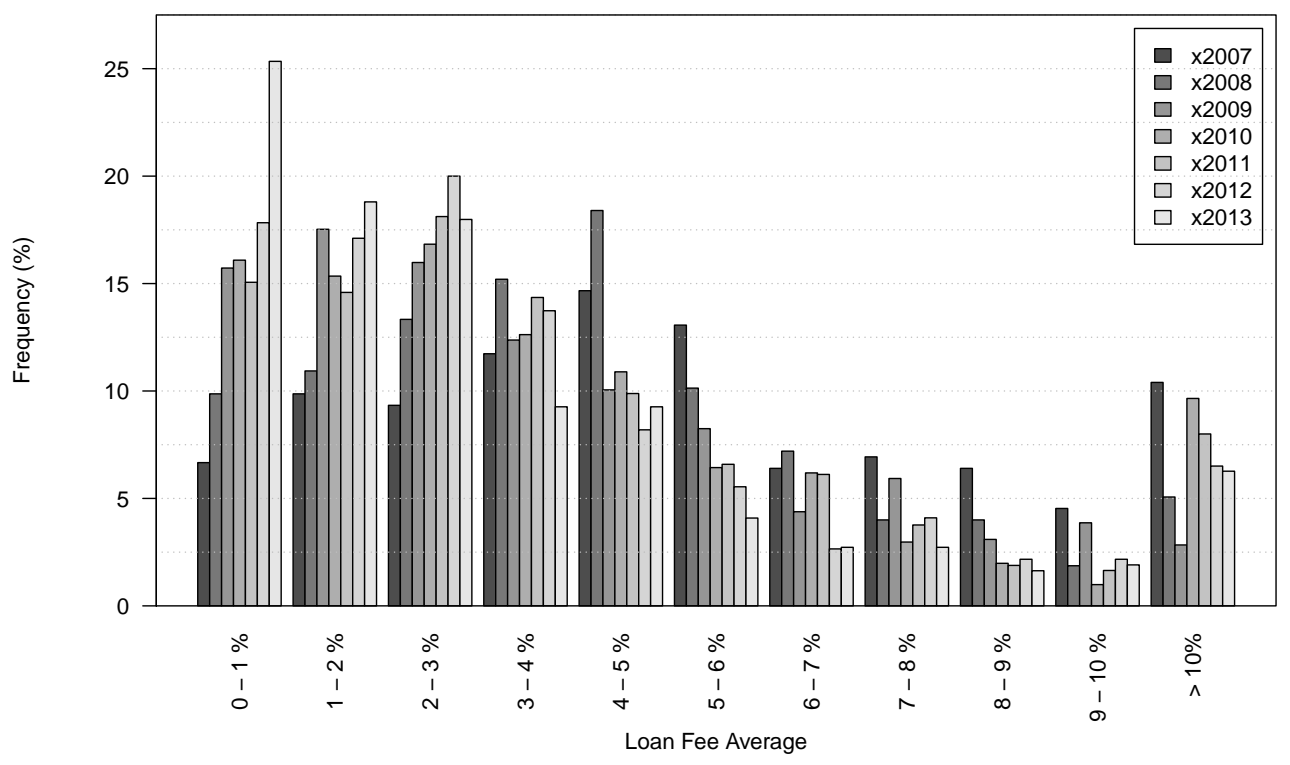

Figure 5. Distribution of Loan Fees By Firms by Year

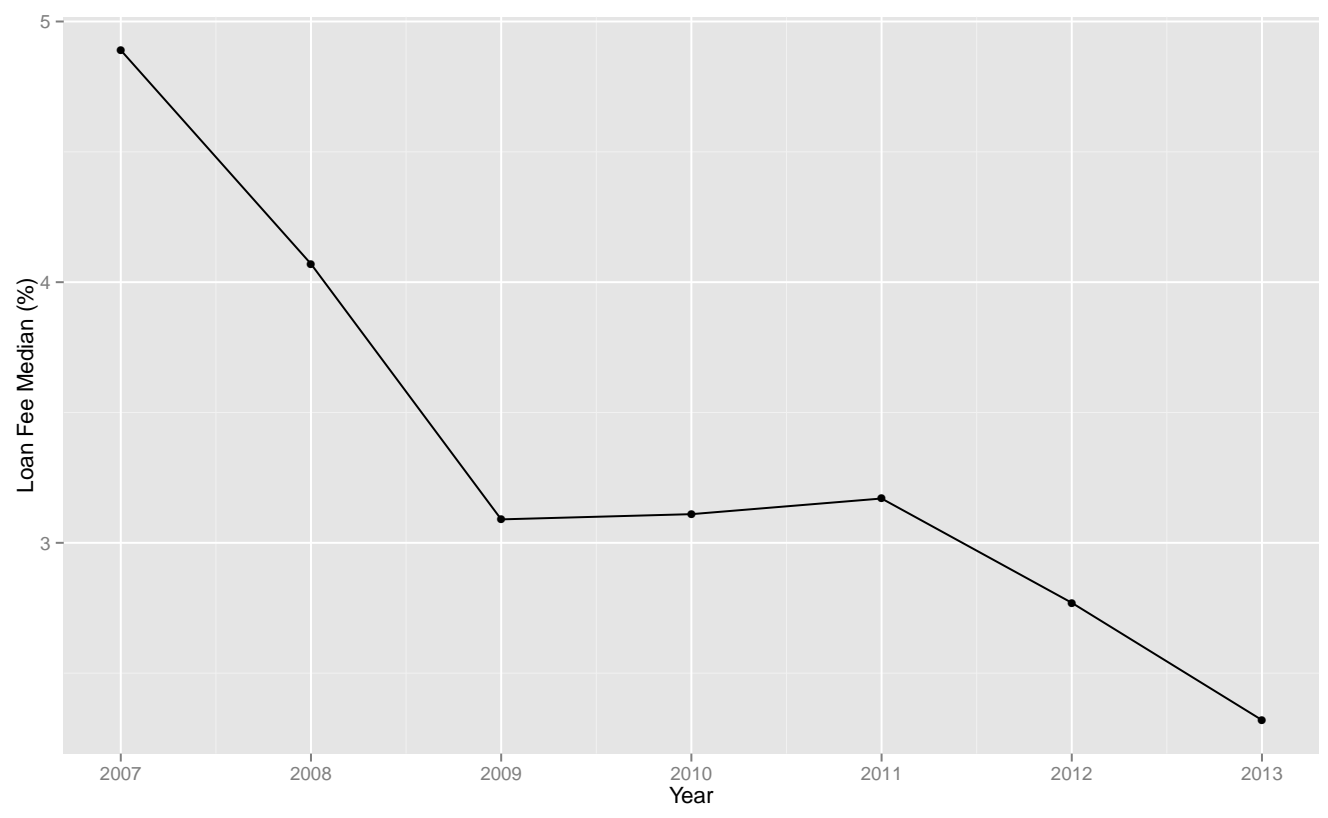

Figure 6. Median of Loan Fees Through Time 


\section{The Tax Arbitrage}

In the last years a tax arbitrage involving equity loans had important effect in the equity loan market, causing spikes in both short interest and loan fees around the IoNE payout date. The tax arbitrage opportunities appear during IoNE payout, which is subject to an income tax of $15 \%$. However, domestic mutual funds are exempt.

IoNE is one of the two ways a firm in Brazil can distribute profits to its shareholders. The IoNE was created in 1995 and its taxation method is justified by Brazilian policymakers as an incentive to companies increase their capitalization. The main difference between dividend payments and IoNE is the different tax treatment. IoNE paid to equity shareholders, are deductible from corporate taxable income, while dividends are not. As a counterpart to that, shareholders who receive dividends are tax exempt, while IoNE recipients are not. There is, however, an upper limit on the payment of IoNE of $50 \%$ of net income. Since corporations have a tax incentive to distribute profits through IoNE instead of dividends they tend to do it preferentially up to that limit.

Recipients of IoNE payments are subject to withholding income tax rate of $15 \%$, except for those who are exempt, as mutual funds, for example. This difference in tax treatment generates a tax arbitrage, which consists on retail and foreign investors lending stocks to mutual funds at the time a tax payment would be due. Since during the loan contract the security ownership belongs to the borrower, if there is a IoNE event during a loan contract, the borrower will receive the remuneration according to his tax status: a mutual fund will receive the total IoNE without tax withholdings. When the loan contract is liquidated the fund must reimburse the lender the payout payment he would receive if he had the stock custody. So, he will refund the lender the

amount of the IoNE payment discounted by the tax amount the lend would pay. The incentives for the lending activity around IoNE payouts are clear: retail and foreign investors gain the loan fee and domestic mutual funds the 
tax evaded ( $15 \%$ of the IoNE) minus the loan fee.

In figure 7 we show the flowchart of important dates for the tax arbitrage. The first date is the earning announcements, an official public statement of a company's profitability for a specific time period, typically a quarter or a year. Based on the earning announcements and the company's history, the investors are capable to forecast the amount of payouts in form of dividends and IoNE. The earning announcements usually follow earning announcements seasons. The second date is the payout announcement, on which the next IoNE payment is announced by the directors of a company, as well as the IoNE's value per share, ex-date date and payment dates. Although there is not a fixed period after the earning announcement date, the payout announcement usually takes place a month after it. The next is the ex-date, stocks traded on or after the ex-date to not receive the announced IoNE. The ex-date is at least one business day after the payout announcement, which is the most common to happen, although there are some events that this interval is larger. The record date is the date established by an issuer of a security for the purpose of determining the holders who are entitled to receive a dividend or distribution. The time period of three business days between the cum-date and the record date is due to the fact that trades that take place on the cum-date are liquidated at the record date, in accordance of the three business days liquidation period of the exchange. Finally there is the payment date, which can vary from some days to months.

Different from a normal trade, a loan contract takes place instantaneously. The record date is then the crucial date to the tax arbitrage opportunity. It is the day on which the tax exempt investor must hold the stock and the IoNE is recorded and his name. So any loan contract - from non tax exempt to a tax exempt - that takes place in the the day or before the record date and liquidated after it is an arbitrage contract. 


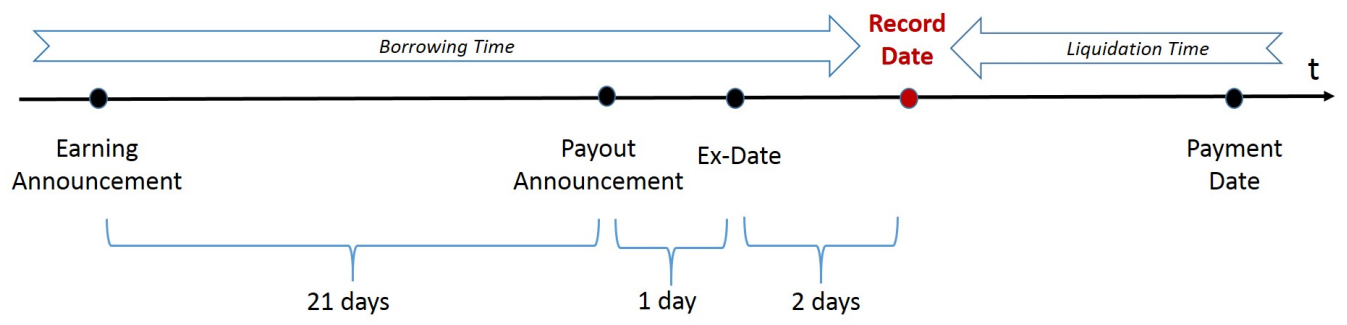

Figure 7. Typical dates flowchart for the IoNE event.

While the profit of the mutual funds in the arbitrage transaction is the $15 \%$ share of the IoNE total value, the profit of individual investors (retail and foreign) is the fee gained in the loan transaction. AS expected, we observe a sharpe increase in the loan fee during the IoNE event. In the graph of Figure 8 we observe that 21 business days before IoNE record date the average loan fee is $2.3 \%$. It increases until the record date, where it reaches $11.5 \%$. The three days before the peak, where the steep becomes much higher, corresponds to the time difference between the IoNE announcement and the record date. During this period the exactly value of the IoNE is known and there is no more uncertainty about the arbitrage profit.

It is interesting to notice, though, that the loan fee increase does not happen for the arbitrage contracts, but for all loan contracts. In figure 9 we analyze the loan fee increase for arbitrage contracts separately from nonarbitrage contracts. As expected the loan fee increase for arbitrage contracts is sharper, it increases from $2.16 \% 21$ days before the IoNE's record date to $12.14 \%$ at the record date. The non-arbitrage loan fee goes $2.31 \%$ from to $3.41 \%$ a relative increase of $47 \%$. 
Figure 8. Loan Fee around Record Date of an IoNE event

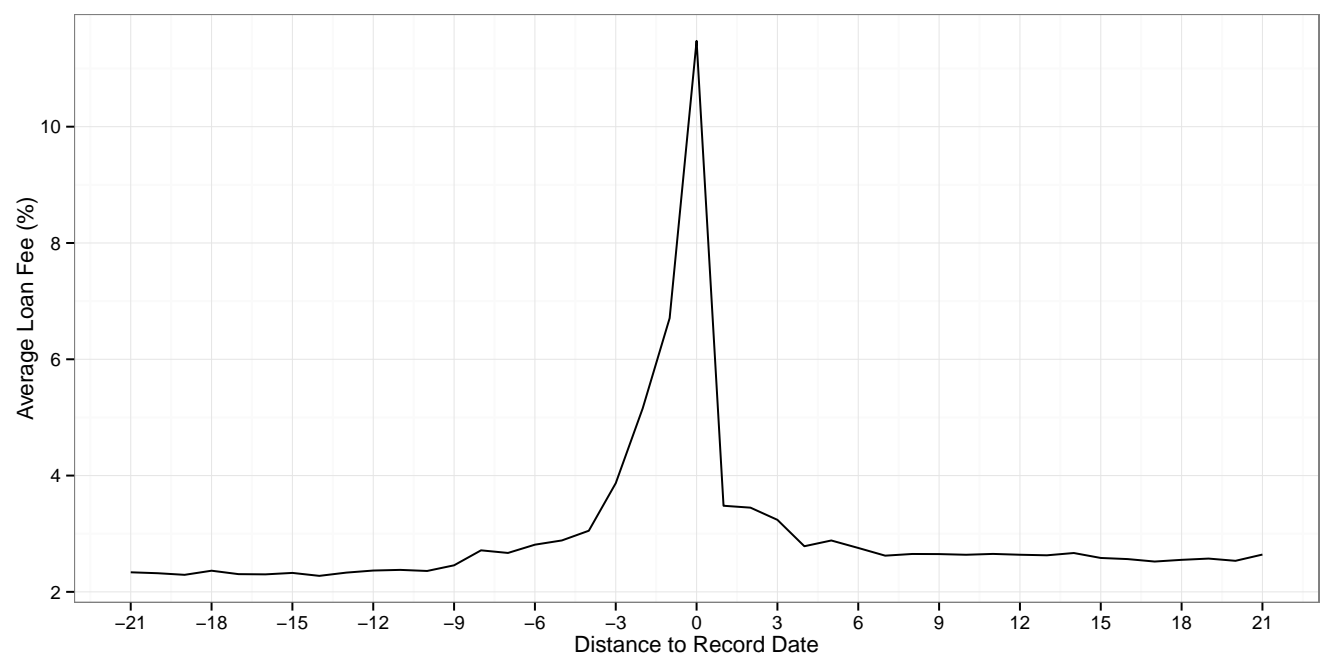

Figure shows the average loan fee around the record date of the IoNE event. The daily loan fee for each share is the value weighed fee among all contracts in a certain day. The average loan fee is the common mean among shares. We consider 487 IoNE events from January 2010 until June 2013. 
Figure 9. Loan Fee around Record Date of an IoNE event by Groups

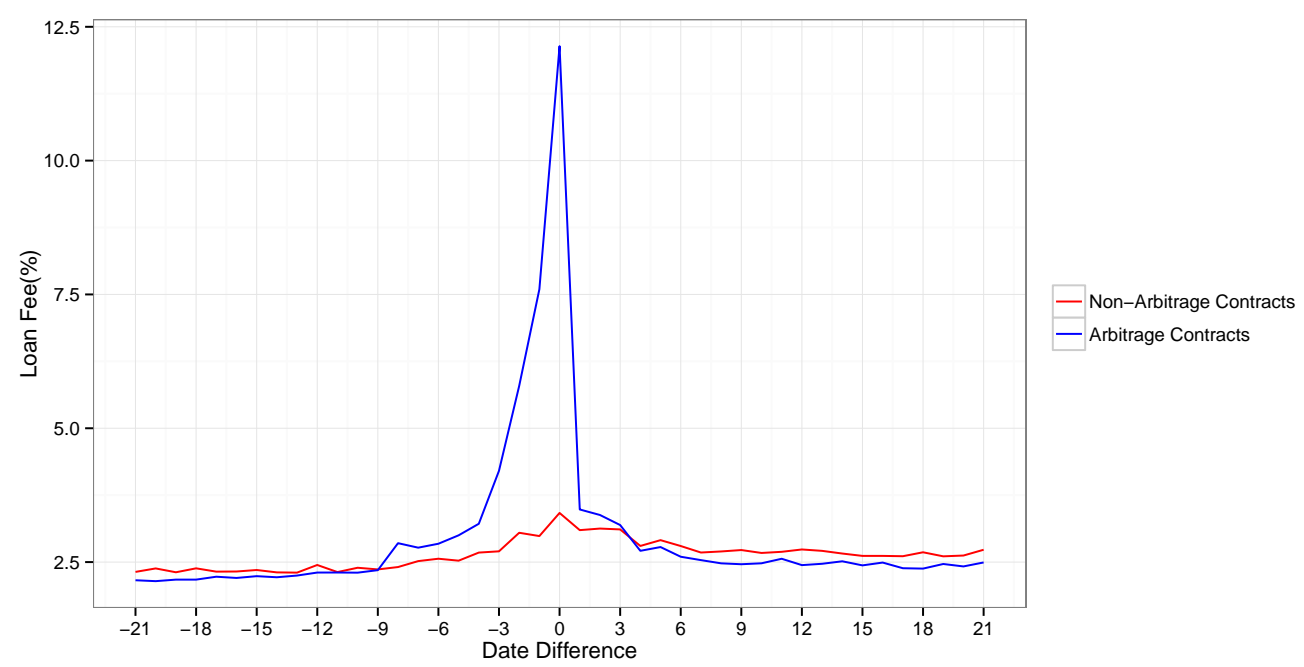

(a) Loan Fee for Groups of Contracts

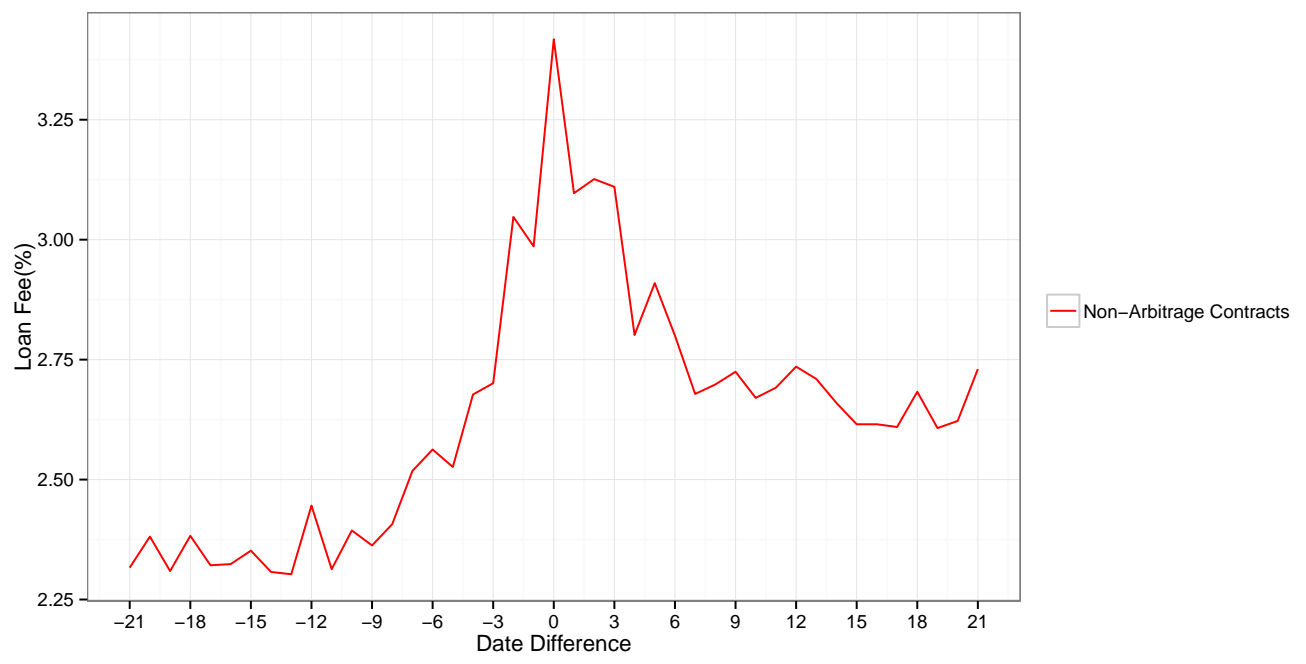

(b) Loan Fee for Non-Arbitrage Contracts

Arbitrage loan contracts are the ones that have tax benefits - i.e, borrowers are mutual funds and lenders are retail investors or foreign investors. Non-Arbitrage contracts are the other contracts. We define the daily loan fee as the value weithed average loan fee for each stock and each day around the IoNE date. The figure shows the average loan fee among all stocks for each day around the IoNE record date. 
Figure 10 depicts the short-interest graph, which shows a similar pattern. 21 business days before IoNE record the average short-interest is $1.6 \%$, increasing to $3.6 \%$ on the record date. The pattern in both figures is driven by the tax arbitrage opportunity, as we document in the next section.

Figure 10. Short-Interest around Record Date of an IoNE Event

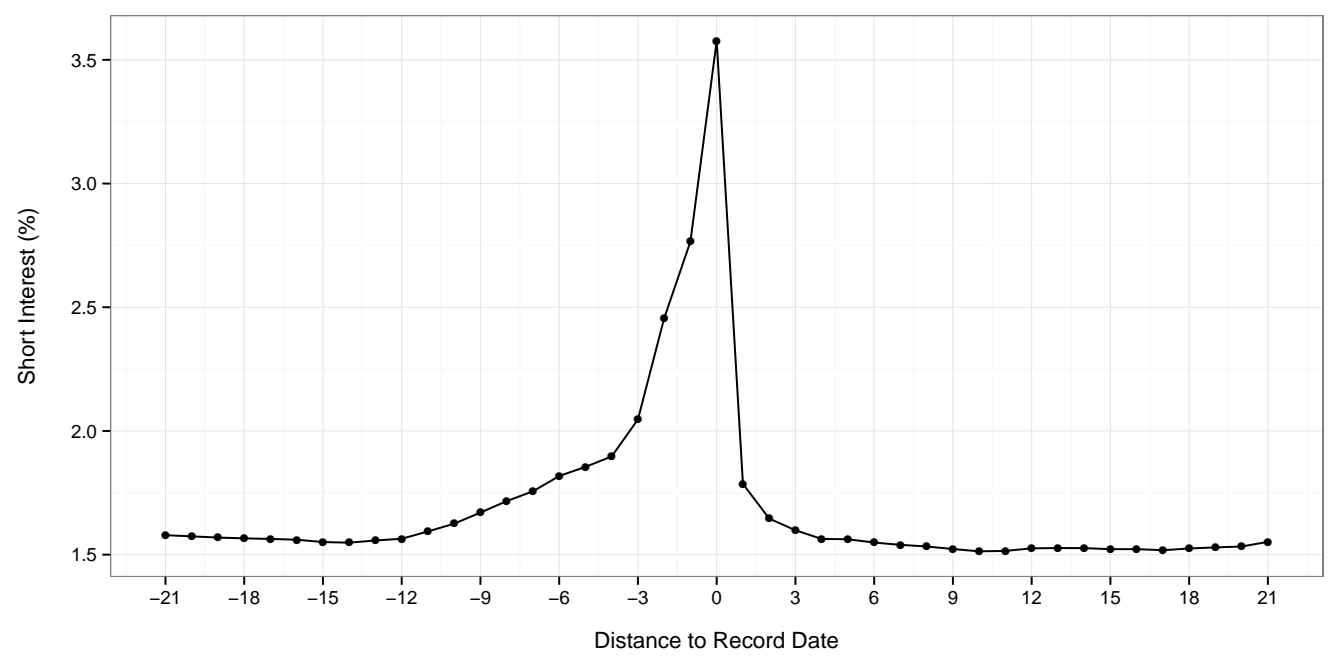

Figure shows the average short-interest around the record date of the IoNE event. The average short-interest is the common mean among shares. We consider 487 IoNE events from January 2010 until June 2013.

We calculate the returns around the IoNE record date. Interestingly we also observe consistent positive abnormal return for the stocks that distribute IoNE. In figure $12(\mathrm{a})$ we can see that in for the 5 days prior to the record date we observe daily positive statistically significant, the daily average return is $12 \mathrm{bps}$ and cumulative return for the 5 days period is 0.62 bps (which is positive at $5 \%$ significance level). In Figure 12(b) we observe that the positive abnormal return persists even in a longer period around the IoNE record date. 
Figure 11. Abnormal Returns around the IoNE Date

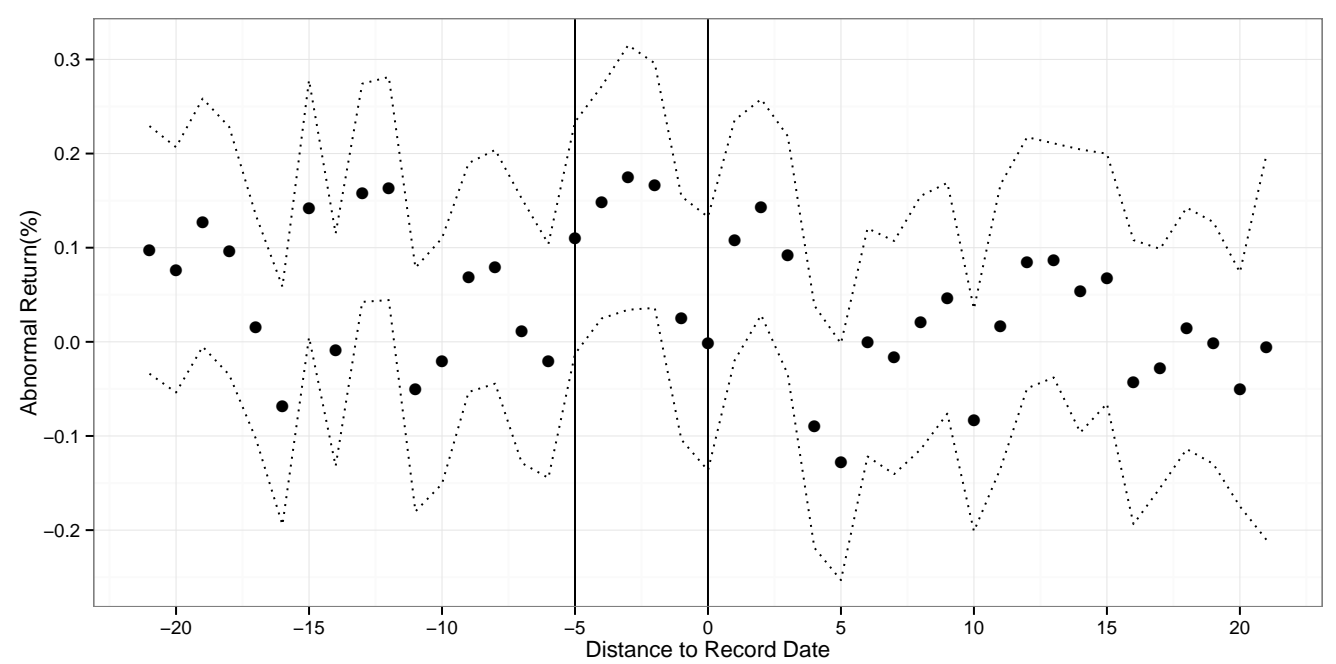

(a) Daily Abnormal Return

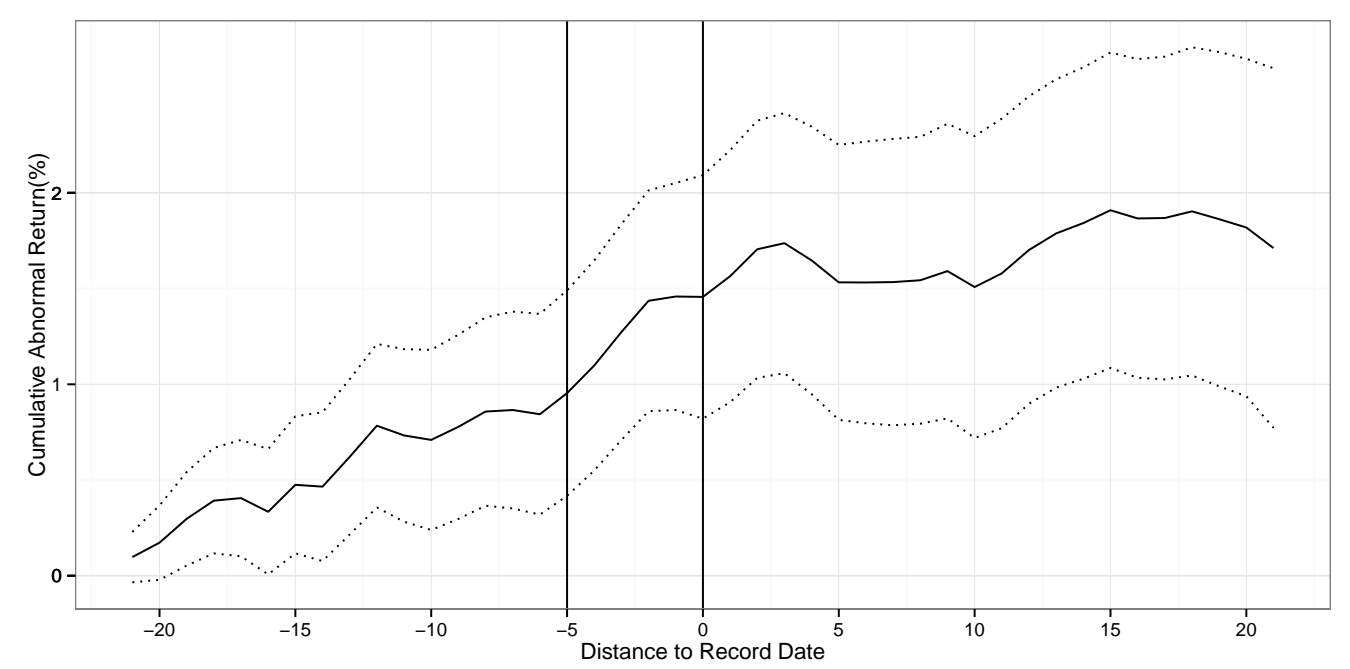

(b) Cumulative Abnormal Return

Abnormal return is calculated as the stock return minus the stock loading on the market portfolio IBX50, that accounts for the first 50 biggest stocks in market capitalization. For each IoNE we calculate the abnormal return in the event window of 21 days before and after an IoNE event. (a) shows the average abnormal return for each day around the record day of the IoNE, while (b) accumulates the abnormal from the 21 days before the IoNE record date until 21 days after. The dotted line is the $90 \%$ percent confidence interval. 


\section{Data}

BM\&FBovespa, the stock exchange, keeps records for the complete market in all stages of trade. It treats a loan transaction as a process of three different stages: offers, contracts and liquidation. The data of each stage is recorded in three relational data bases in a way that the whole loan transaction process can be tracked, as well as specific information about investors, brokers and maturity.

We have collected data for the period that goes from January 2010 to June 2013.The dataset information used in this paper is: contract date, liquidation date, loan fee, quantity of shares and final investor typ $4^{4}$. Together with dataset Radar, that provides data about payouts events, we are capable of identifying loan contracts that are eligible for tax arbitrage. Arbitrage contract are, then, contracts in which the lenders are retail or foreign investor and the borrowers mutual funds that took place before or on an IoNE record date and were liquidated after it.

To collect data about stocks returns we use Economática. Abnormal return is calculates as the stock return minos the stock exposition to the market portfolio IBX50, that accounts for the first 50 biggest stocks in market capitalization. For each IoNE we calculate the abnormal return in the event window of 21 days before and after an IoNE event. The estimation window is on year, i.e., 126 days before the event and 126 days after it. To be consider, a stock must present at least 126 of valid prices in the estimation window and have valid prices in the event window.

An IoNE event to be considered must have arbitrage contracts that took place in the five days before the record date of the event. The stock must have valid abnormal return in the event window, as well as valid turnover date for the last 21 days before the record date. We have than 487 valid IoNE events of 96 different stocks. This stocks together represents roughly $70 \%$

\footnotetext{
${ }^{4}$ The data is from BM\&FBovespa, who kindly made the data available for this research.
} 
of BM\&FBovespa market capitalization. In table II we show the summary statistics for theses events.

Table IISummary Statistics

\begin{tabular}{ccccccc}
\hline & mean & $\min$ & median & $\max$ & std.dev & obs. \\
\hline \hline Abnormal Return $\left(r_{\tau-5, \tau+5}\right)$ & 0.746 & -22.122 & 0.563 & 17.998 & 5.307 & 487 \\
Arbitrage Short-Interest $(\%)$ & 1.506 & 0.0001 & 0.700 & 27.084 & 2.804 & 487 \\
Arbitrage $\Delta F e e$ & 6.109 & -0.929 & 1.292 & 74.075 & 10.850 & 487 \\
Non-Arbitrage $\Delta F e e$ & 0.713 & -0.851 & 0.091 & 19.971 & 2.011 & 487 \\
IoNE & 0.009 & 0.0001 & 0.007 & 0.157 & 0.013 & 487 \\
Turnover & 0.317 & 0.001 & 0.242 & 1.698 & 0.254 & 487 \\
Median Fee & 2.149 & 0.279 & 1.842 & 15.552 & 1.965 & 487 \\
Liquidity & 1.009 & 0.003 & 0.445 & 10.965 & 1.582 & 487 \\
\hline
\end{tabular}

Abnormal returns are the cumulative abnormal return from 5 days before the record date of the event until 5 days after it. Abnormal return is calculated as the stock return minos the stock loading on the market portfolio IBX50, that accounts for the first 50 biggest stocks in market capitalization. For each IoNE we calculate the abnormal return in the event window of 21 days before and after an IoNE event. The estimation window is on year, i.e., 126 days before the event and 126 days after it. Arbitrage loan contracts are the ones that have tax benefits - i.e, borrowers are mutual funds and lenders are retail investors or foreign investors - that took place in the 5 days window before the IoNE event. Arbitrage Short-Interest is the total shares involved in arbitrage loan contracts divided by the total shares outstanding in the record day. Arbitrage $\Delta F e e$ is the relative loan fee increase during the IoNE window for arbitrage contracts. Non-Arbitrage $\Delta F e e$ is the relative loan fee increase during the IoNE window for non-arbitrage contracts. IoNE is the IoNE value per share normalized by the ex-date price. Turnover is the average turnover in the 30 days before the IoNE event. Median loan fee the median loan fee for the 30 days before the IoNE event. Liquidity is defined in equation 1.

\section{Identification Strategy}

The events of distribution of Interest of Net Equity (IoNE) are the source of exogenous variation to estimate the causal impact of short-selling restric- 
tions on returns. Entitlement over the distribution of the IoNE is determined by the ownership of the stock at the date of the actual distribution. In other words, the IoNE accrues to whomever holds the stock when the IoNE is distributed.

As explained above, the tax arbitrage operation consists of individuals lending the stock to mutual funds. Figure 9 shows a sharp increase in fees in lending transaction from individuals to mutual fund respond around the events of IoNE distribution. Figure 10 depicts a sharp increase in shortinterest. Fees in lending transaction from individuals to mutual fund start to increase around fifteen trading days before the event. They spike sharply a few days before the event, reaching a peak the day prior to the event, and then dropping sharply after the event but still reaching a historically high level the new 10 days after the event, returning to normal levels some 18 trading days after the event. On average, lending increase fivefold and short-interest more than double during the events of IoNE distribution.

Fees in lending transactions that are not beneficiated by the tax arbitrage opportunity - we call them non-arbitrage transaction - follow the same dynamics around the event, but less intensively. Fees on non-arbitrage transactions increase from an average of $2.31 \%$ to $3.41 \%$,an increase of almost $48 \%$ at the height of event. The non-arbitrage lending market suffers a negative supply shock of stocks available due to the use of stocks in arbitrage transactions, i.e., from individuals to mutual funds. Under certain identification assumptions, the changes in lending fees on arbitrage transactions provide exogenous variation on short-selling restrictions because issuing a negative opinion on the stock by short-selling becomes momentarily more expensive.

We show that the magnitude in the increase in fees in non-arbitrage transactions is strongly associated with the increases in fees and short-interest in the arbitrage transactions (the first-stage). The identification assumption is that the magnitudes of the increases in fees and short-interest in arbitrage transactions are exogenous to the short-selling market. In this case, vari- 
ations in the increase in fees in non-arbitrage transactions are tantamount to experimental variation in short-selling restrictions. In some events the increase in short-selling restrictions are steeper than others for random reasons. In other words, changes in fees and short-interest in arbitrage transaction are instruments to changes in fees in non-arbitrage transactions. One may argue that prices (lending fees) and quantities (the amount of stocks lent in arbitrage transactions) capture the same phenomenon, and thus are only one instrument. We take an agnostic stand and verify in the first stage whether on instrument contributes to explaining the endogenous variable (lending fees in arbitrage transactions) above and beyond other. Evidently, the additional payoff in terms of stronger first stage is important. But more importantly, having two instruments allows us to test whether the model is overidentified.

We argue that it is reasonable to assume that changes in fees and shortinterest in arbitrage transactions are exogenous. We regress the magnitudes of the increases in arbitrage short-interest and fee on several covariates. Table III has the results. In a nutshell, the increase in arbitrage fees and, to a lesser extent, in arbitrage short-interest is determined by the amount of IoNE distribution. This is expected because the amount of IoNE determines the size of the pie to appropriated in the tax arbitrage procedure. The share of the pie approbated by lender is materialized by the increase in lending fees in arbitrage transactions. The formal announcement of the amount of IoNE distribution is made within 3 days of the event. Thus, if the size of the IoNE signals something about the value of the firm, then our identification strategy is not valid. 
Table IIIInstrument Regressions

\begin{tabular}{|c|c|c|c|c|}
\hline & \multicolumn{4}{|c|}{ Dependent variable: } \\
\hline & \multicolumn{2}{|c|}{ Arbitrage Short-Interest } & \multicolumn{2}{|c|}{ Arbitrage $\Delta f e e$} \\
\hline & (1) & $(2)$ & $(3)$ & $(4)$ \\
\hline IoNE & $\begin{array}{c}32.566^{* * *} \\
(6.825)\end{array}$ & $\begin{array}{c}22.087^{* * *} \\
(6.397)\end{array}$ & $\begin{array}{c}738.186^{* * * *} \\
(60.986)\end{array}$ & $\begin{array}{c}679.121^{* * *} \\
(57.636)\end{array}$ \\
\hline Turnover & & $\begin{array}{l}1.732^{* * * *} \\
(0.372)\end{array}$ & & $\begin{array}{l}7.705^{* *} \\
(3.353)\end{array}$ \\
\hline Median Loan Fee & & $\begin{array}{c}0.041 \\
(0.062)\end{array}$ & & $\begin{array}{l}-0.344 \\
(0.558)\end{array}$ \\
\hline Median Short-Interest & & $\begin{array}{c}-0.181^{* * *} \\
(0.043)\end{array}$ & & $\begin{array}{c}-3.403^{* * *} \\
(0.392)\end{array}$ \\
\hline Constant & $\begin{array}{l}1.282^{* * *} \\
(0.093)\end{array}$ & $\begin{array}{c}0.700^{* * *} \\
(0.126)\end{array}$ & $\begin{array}{l}6.244^{* * *} \\
(0.829)\end{array}$ & $\begin{array}{l}7.656^{* * *} \\
(1.138)\end{array}$ \\
\hline Observations & 487 & 487 & 487 & 487 \\
\hline $\mathrm{R}^{2}$ & 0.045 & 0.202 & 0.232 & 0.347 \\
\hline Adjusted $\mathrm{R}^{2}$ & 0.043 & 0.195 & 0.230 & 0.342 \\
\hline
\end{tabular}

Several facts suggest that the size of the distribution of IoNE contains no information about the value of the firm. Quite simply, although the formal announcement is within the event window, in practice the amount of IoNE is known when earnings are announced, which is outside the window of the events. Shareholders dividends are tax free. IoNE pays $15 \%$ (the taxation on interest). For companies in the sample, the corporate tax rate on earnings is at least 24\%.5. Companies almost always distribute the legal allowed maximum in IoNE. 6

\footnotetext{
${ }^{5}$ Almost all companies in our sample operate under the so-called Real Income regime. The Real Income regime is progressive. Companies pay a $15 \%$ tax rate on annual incomes up to BRL 240,000.00, approximately USS89,000.00; above this threshold companies pay an additional $15 \%$ surcharge. Almost all companies in our sample have annual income well above the threshold.

${ }^{6}$ There are two legal limits. One is the minimum payout, which can be dividends or
} 
We weight observations by their stock liquidity. Stocks vary quite wildly in liquidity, which implies a wide variation in return's volatility. The model for the variance has empirical support in our data. We use a liquidity indicator as:

$$
\text { Liquidity }=100 * p / N * \operatorname{sqrt}(n / N * v / V)
$$

where p period considered in business days - we chose one month period, 21 business days-, $\mathrm{n}$ is the number of trades of the stock in the period $\mathrm{p}, \mathrm{N}$ is the number of total trades in the exchange in period $\mathrm{p}, \mathrm{v}$ is the monetary value of all trades of the stock in period $\mathrm{p}$ and $\mathrm{V}$ is the total volume of trades in the exchange in period $\mathrm{p}$.

We estimate the reduced-form regression of accumulated returns (from -5 to +5 trading days around the event) on exogenous variables:

$$
\begin{array}{r}
\text { Return }_{e}=\beta_{0}+\beta_{1} \text { Liquidity }_{e}+\beta_{2} \text { ArbShortInt }_{e}+\beta_{3} \Delta \text { ArbFee }_{e}+ \\
\beta_{4} \text { IoNE }_{e}+\beta_{5} \text { Turnover }_{e}+\beta_{6} \text { MedianLoanFee }_{s}+\epsilon_{e}
\end{array}
$$

The subscript $e$ is an event. Liquidity is defined in equation 1, ArbShortInt is the total shares involved on arbitrage contracts normalized the total shares outstanding, $\triangle$ ArbFee is the change in the lending fee on arbitrage transactions, IoNE is the IoNE per share normalized by the ex-date price, Turnover is the average daily turnover of the stock in the last month before the record date of the IoNE, and MedianFee is the median fee on lending transactions

We square the residuals of (2) and regress them on the same exogenous variables in (2).

IoNE. Given an amount distributed, companies try to maximize the IoNE. The IoNE is given by net worth times the Long-Term Interest Rate, a prime rate determined by the federal government; the value is limited to the maximum of $50 \%$ of the current period earnings before corporate taxes, and $50 \%$ of the accumulated earnings and reserves in previous periods. 
Table IVVolatility Model

\begin{tabular}{|c|c|c|}
\hline & \multicolumn{2}{|c|}{ Dependent variable: } \\
\hline & \multicolumn{2}{|c|}{ Squared Residuals of Equation 2} \\
\hline & (1) & $(2)$ \\
\hline Liquidity & $\begin{array}{c}-4.535^{* * *} \\
(0.986)\end{array}$ & $\begin{array}{c}-5.991^{* * *} \\
(1.735)\end{array}$ \\
\hline Arbitrage Short Interest & & $\begin{array}{l}1.034^{*} \\
(0.528)\end{array}$ \\
\hline$\Delta$ Arbitrage Fee & & $\begin{array}{c}-0.740 \\
(0.516)\end{array}$ \\
\hline IoNE & & $\begin{array}{c}444.818 \\
(331.424)\end{array}$ \\
\hline Turnover & & $\begin{array}{l}36.964^{* *} \\
(16.754)\end{array}$ \\
\hline Median Loan Fee & & $\begin{array}{c}0.156 \\
(1.473)\end{array}$ \\
\hline Constant & $\begin{array}{c}32.686^{* * *} \\
(3.093)\end{array}$ & $\begin{array}{c}18.947^{* * *} \\
(4.535)\end{array}$ \\
\hline Observations & 487 & 487 \\
\hline $\mathrm{R}^{2}$ & 0.019 & 0.061 \\
\hline Adjusted $\mathrm{R}^{2}$ & 0.017 & 0.050 \\
\hline
\end{tabular}

Robust standard errors corrected for clustering at the ticker level. Regression of the squared residuals of the reducedform on the exogenous variables. Reduced-form: Return $n_{e}=$ $\beta_{0}+\beta_{1}$ Liquidity $_{e}+\beta_{2}$ ArbShortInt $_{e}+\beta_{3} \Delta$ ArbFee $_{e}+\beta_{4}$ IoNE $_{e}+$ $\beta_{5}$ Turnover $_{e}+\beta_{6}$ MedianLoanFee $_{s}+u_{e}$.

${ }^{*} p<0.1 ;{ }^{* *} p<0.05 ;{ }^{* * *} p<0.01$. 
Estimates in column (1) show liquidity has a strong statistical impact on the estimated variance. In column (2) we include the other exogenous variables. The impact of liquidity is even stronger.

The main object of interest is the impact of non-arbitrage fees on returns, which provides a measure of the impact of short-selling restrictions on returns.

$$
\text { Return }_{e}=\alpha+\beta \Delta \text { NonArbFee } e_{e}+\text { Controls }+u_{e}
$$

where NonArbFee is the change in the fee on non-arbitrage contracts during the event. Controls include liquidity, turnover, median fee, median short interest and the IoNE per share. The excluded exogenous variables are the instruments: increases in fees and short-interest on arbitrage transactions. Excluding the instruments from (2) is equivalent to identification hypothesis. During the event, period changes in the fees and short-interest on arbitrage transactions contain no relevant information for returns.

The first stage is:

$$
\begin{array}{r}
\Delta \text { NonArbFee }_{e}=\beta_{0}+\beta_{1} \text { ArbShortInt }_{e}+\beta_{2} \Delta \text { ArbFee }_{e}+ \\
\beta_{3} \text { IoNE }_{e}+\beta_{4} \text { Turnover }_{e}+\beta_{5} \text { MedianLoanFee }_{s}+\epsilon_{e}
\end{array}
$$

\section{Results}

We present the results of the first-stage, i.e., $\triangle$ NonArbFee on all exogenous variables, and the second stage, returns on $\Delta N$ on ArbFeeinstrumentd by ArbShorInt and $\triangle$ ArbFee.

\section{A. Reduced Form}

Table $\mathrm{V}$ contains the results of the reduced-form, when we regress the cumulative returns within the event window on the instruments. In column (1) 
we include only the short-interest in arbitrage operations: abnormal returns are statisitcally related to the size of the short-interest in arbitrage transactions. The typical increase in short-interest during the event is roughly $1.5 \%$. Using the coefficient in column (1), we find that abnormal returns of $1.5 \times 0.485=0.72$ percentage point. In column $(2)$ we regress the abnormal returns on the size of the increase in fees in arbitrage transactions. Again, the larger the increase in arbitrage fees, the higher are abnormal returns. The same exercise yields a 0.33 percentage point abnormal returns during the event.7 When both instruments are included (column 3), both instruments explain abnormal reruns. The impact during the event is roughly 0.84 percentage. Column 4 presents OLS results: regressing abnormal returns on the increase in fees in non-arbitrage transactions. We find no impact on abnormal returns of increases in fees in non-arbitrage transactions. This is not surprising because most of the variation in fees in non-arbitrage transactions is endogenous. Finally, in column 5 we include the instruments and the endogenous variable, and reach the same conclusions as in columns 3 and 4 .

In summary, the reduced-form shows that the stock experience significant abnormal returns during events of IoNE distribution. No structural interpretation is warranted. The following section reports the second stage, which associates this abnormal returns with the exogenous part of the increase in non-arbitrage transactions' fees. Differently from the reduced-form, this object has a structural interpretation: the higher the price to issue a negative opinion about the stock, the larger the abnormal return.

\footnotetext{
${ }^{7}$ Table II shows that the typical increase in fees in arbitrage transaction is approximately $6.31 \%$. We multiply this by 0.052 , the coefficient in column 2 .
} 
Table VReduced Form Results

\begin{tabular}{|c|c|c|c|c|c|}
\hline & \multicolumn{5}{|c|}{ Dependent variable: Cumulative Returns from -5 to 5} \\
\hline & \multicolumn{3}{|c|}{ Reduced Form } & \multicolumn{2}{|c|}{ OLS } \\
\hline & $(1)$ & $(2)$ & $(3)$ & (4) & $(5)$ \\
\hline Arbitrage Short Interest & $\begin{array}{c}0.485^{* *} \\
(0.206)\end{array}$ & & $\begin{array}{c}0.392^{*} \\
(0.203)\end{array}$ & & $\begin{array}{c}0.435^{*} \\
(0.225)\end{array}$ \\
\hline$\Delta$ Arbitrage Fee & & $\begin{array}{c}0.052^{* * *} \\
(0.017)\end{array}$ & $\begin{array}{l}0.040^{* *} \\
(0.016)\end{array}$ & & $\begin{array}{c}0.046^{* * *} \\
(0.017)\end{array}$ \\
\hline$\Delta$ Non-Arbitrage Fee & & & & $\begin{array}{c}0.058 \\
(0.106)\end{array}$ & $\begin{array}{l}-0.088 \\
(0.107)\end{array}$ \\
\hline IoNE & $\begin{array}{l}-12.840 \\
(34.340)\end{array}$ & $\begin{array}{l}-37.520 \\
(32.023)\end{array}$ & $\begin{array}{l}-38.409 \\
(30.754)\end{array}$ & $\begin{array}{c}-6.764 \\
(39.804)\end{array}$ & $\begin{array}{l}-36.228 \\
(31.574)\end{array}$ \\
\hline Turnover & $\begin{array}{l}-1.905 \\
(1.535)\end{array}$ & $\begin{array}{l}-1.276 \\
(1.393)\end{array}$ & $\begin{array}{l}-1.967 \\
(1.369)\end{array}$ & $\begin{array}{l}-0.994 \\
(1.666)\end{array}$ & $\begin{array}{l}-2.041 \\
(1.350)\end{array}$ \\
\hline Median Loan Fee & $\begin{array}{c}0.019 \\
(0.179)\end{array}$ & $\begin{array}{c}0.110 \\
(0.166)\end{array}$ & $\begin{array}{c}0.141 \\
(0.173)\end{array}$ & $\begin{array}{l}-0.043 \\
(0.203)\end{array}$ & $\begin{array}{c}0.131 \\
(0.181)\end{array}$ \\
\hline Constant & $\begin{array}{c}0.932^{*} \\
(0.497)\end{array}$ & $\begin{array}{c}0.881^{* *} \\
(0.423)\end{array}$ & $\begin{array}{l}0.689^{*} \\
(0.400)\end{array}$ & $\begin{array}{l}1.213^{* *} \\
(0.507)\end{array}$ & $\begin{array}{l}0.710^{*} \\
(0.401)\end{array}$ \\
\hline Observations & 487 & 487 & 487 & 487 & 487 \\
\hline $\mathrm{R}^{2}$ & 0.032 & 0.029 & 0.045 & 0.007 & 0.048 \\
\hline Adjusted $\mathrm{R}^{2}$ & 0.024 & 0.021 & 0.035 & -0.001 & 0.036 \\
\hline
\end{tabular}

Robust standard errors corrected for clustering at the ticker level. We present the results of regressions of the cumulative abnormal return from 5 days before the record date of the event until 5 days after it. The exogenous variables are the Arbitrage Short Interest, $\Delta$ Arbitrage Loan Fee, Turnover and Median Loan Fee. The endogenous variable is the $\Delta$ Non-Arbitrage Loan Fee. Observations weighted by the stock liquidity.

${ }^{*} p<0.1 ;{ }^{* *} p<0.05 ;{ }^{* * *} p<0.01$.

\section{B. First Stage}

Table VI presents the results on first stage. Instruments are strongly related to the endogenous variable - the change in fees in non-arbitrage transactions. We include the two instruments - the change in fee in arbitrage transactions and the amount of short-interest - separately (columns 1 and 2 ). In both cases the instrument is significant at the $5 \%$ level. When included jointly, the instruments are, if anything, more significant. Thus, we have strong instruments. 
Table VIFirst Stage

\begin{tabular}{|c|c|c|c|}
\hline & \multicolumn{3}{|c|}{ Dependent variable: } \\
\hline & \multicolumn{3}{|c|}{$\Delta$ Non-Arbitrage Fee } \\
\hline & (1) & $(2)$ & $(3)$ \\
\hline Arbitrage Short Interest & $\begin{array}{l}0.624^{* *} \\
(0.260)\end{array}$ & & $\begin{array}{c}0.509^{* * *} \\
(0.194)\end{array}$ \\
\hline$\Delta$ Arbitrage Fee & & $\begin{array}{l}0.251^{* *} \\
(0.104)\end{array}$ & $\begin{array}{c}0.203^{* *} \\
(0.079)\end{array}$ \\
\hline IoNE & $\begin{array}{l}63.171^{* *} \\
(27.694)\end{array}$ & $\begin{array}{l}-53.976 \\
(48.799)\end{array}$ & $\begin{array}{l}-39.542 \\
(39.048)\end{array}$ \\
\hline Turnover & $\begin{array}{c}-0.738 \\
(0.882)\end{array}$ & $\begin{array}{c}0.204 \\
(0.681)\end{array}$ & $\begin{array}{c}-0.728 \\
(0.731)\end{array}$ \\
\hline Median Loan Fee & $\begin{array}{c}-0.298^{* * *} \\
(0.082)\end{array}$ & $\begin{array}{c}-0.218^{*} \\
(0.122)\end{array}$ & $\begin{array}{c}-0.165^{*} \\
(0.098)\end{array}$ \\
\hline Constant & $\begin{array}{c}0.601^{*} \\
(0.326)\end{array}$ & $\begin{array}{c}0.838^{* *} \\
(0.418)\end{array}$ & $\begin{array}{l}0.519^{*} \\
(0.289)\end{array}$ \\
\hline Observations & 487 & 487 & 487 \\
\hline $\mathrm{R}^{2}$ & 0.218 & 0.214 & 0.271 \\
\hline Adjusted $\mathrm{R}^{2}$ & 0.211 & 0.207 & 0.263 \\
\hline
\end{tabular}

Robust standard errors clustered at the ticker level in parentheses. Observations weighted by the stock liquidity.

${ }^{*} p<0.1 ;{ }^{* *} p<0.05 ;{ }^{* * *} p<0.01$.

\section{Second Stage}

Table VII presents the first set of second stage results. First, we show results when weighting observations by the stock liquidity. Instruments predict the endogenous variable both jointly and separately, confirming that both instruments are useful above and beyond the other. 
Table VIIInsturmental Variables

\begin{tabular}{lccc}
\hline \hline & \multicolumn{3}{c}{ Dependent variable: } \\
\cline { 2 - 4 } & & $r_{\tau-5, \tau+5}$ \\
& One Instrument: SI & One Instrument: $\Delta$ Fee & Two Instruments \\
& $(1)$ & $(2)$ & $(3)$ \\
\hline Non-Arbitrage $\Delta$ fee & $0.784^{* *}$ & $0.693^{* *}$ & $0.731^{* * *}$ \\
& $(0.352)$ & $(0.316)$ & $(0.273)$ \\
IoNE & & & $-58.415^{* *}$ \\
& $-62.422^{*}$ & $-55.457^{*}$ & $(27.965)$ \\
Turnover & $(32.071)$ & $(30.506)$ & -1.308 \\
& & & $(1.305)$ \\
Median Loan Fee & -1.333 & -1.290 & 0.232 \\
& $(1.308)$ & $(1.301)$ & $(0.170)$ \\
Constant & 0.253 & & 0.216 \\
& $(0.195)$ & $(0.174)$ & $(0.458)$ \\
\hline Observations & & & -0.179 \\
$\mathrm{R}^{2}$ & 0.458 & 0.553 & \\
\hline \hline
\end{tabular}

This table shows the estimates of equation 3. The depended variable is the cumulative returns. Delta Fee on Non-Arbitrage Transactions instrumented by the amount of short interest in arbitrage transactions and/or by delta fee in arbitrage transactions. Robust standard errors are clustered at the ticker level. Observations are weighted by the stock liquidity.

${ }^{*} p<0.1 ;{ }^{* *} p<0.05 ;{ }^{* * *} p<0.01$.

In order to analyze the persistence of the results over time we estimate equation 3 for different period of return accumulation. 
Table VIIIInsturmental Variables: Analysis of Persistence

\begin{tabular}{|c|c|c|c|c|c|}
\hline & \multicolumn{5}{|c|}{ Dependent variable: } \\
\hline & $\begin{array}{r}r_{\tau-15, \tau-5} \\
(1) \\
\end{array}$ & $\begin{array}{r}r_{\tau-10, \tau} \\
(2) \\
\end{array}$ & $\begin{array}{r}r_{\tau-5, \tau+5} \\
(3) \\
\end{array}$ & $\begin{array}{r}r_{\tau, \tau+10} \\
(4) \\
\end{array}$ & $\begin{array}{r}r_{\tau+5, \tau+15} \\
(5) \\
\end{array}$ \\
\hline Non-Arbitrage Delta fee & $\begin{array}{c}-0.050 \\
(0.174)\end{array}$ & $\begin{array}{c}0.019 \\
(0.223)\end{array}$ & $\begin{array}{c}0.736^{* *} \\
(0.288)\end{array}$ & $\begin{array}{c}0.521^{*} \\
(0.275)\end{array}$ & $\begin{array}{r}-0.311 \\
(0.285)\end{array}$ \\
\hline IoNE & $\begin{array}{c}0.464 \\
(35.477)\end{array}$ & $\begin{array}{c}23.549 \\
(55.274)\end{array}$ & $\begin{array}{c}-58.753^{* *} \\
(27.993)\end{array}$ & $\begin{array}{r}-15.922 \\
(29.169)\end{array}$ & $\begin{array}{l}113.400^{* * *} \\
(30.305)\end{array}$ \\
\hline Turnover & $\begin{array}{c}0.631 \\
(1.028)\end{array}$ & $\begin{array}{c}-0.230 \\
(1.058)\end{array}$ & $\begin{array}{r}-1.310 \\
(1.300)\end{array}$ & $\begin{array}{c}-1.959^{* * *} \\
(0.662)\end{array}$ & $\begin{array}{r}-0.997 \\
(0.843)\end{array}$ \\
\hline Median Loan Fee & $\begin{array}{r}-0.290 \\
(0.200)\end{array}$ & $\begin{array}{c}-0.090 \\
(0.242)\end{array}$ & $\begin{array}{c}0.233 \\
(0.170)\end{array}$ & $\begin{array}{c}0.330^{* *} \\
(0.154)\end{array}$ & $\begin{array}{c}0.126 \\
(0.212)\end{array}$ \\
\hline Constant & $\begin{array}{c}0.784 \\
(0.491)\end{array}$ & $\begin{array}{c}0.816 \\
(0.562)\end{array}$ & $\begin{array}{c}0.508 \\
(0.466)\end{array}$ & $\begin{array}{c}-0.377 \\
(0.387)\end{array}$ & $\begin{array}{c}-0.945 \\
(0.701)\end{array}$ \\
\hline Observations & 483 & 487 & 487 & 487 & 482 \\
\hline $\mathrm{R}^{2}$ & 0.002 & 0.013 & -0.209 & -0.067 & 0.037 \\
\hline Adjusted $\mathrm{R}^{2}$ & -0.007 & 0.004 & -0.219 & -0.076 & 0.029 \\
\hline
\end{tabular}

This table shows the estimates of equation 3. The depended variable is the cumulative returns. Delta Fee on Non-Arbitrage Transactions instrumented by the amount of short interest in arbitrage transactions and by delta fee in arbitrage transactions. Robust standard errors are clustered at the ticker level. Observations are weighted by the stock liquidity. ${ }^{*} p<0.1 ;{ }^{* *} p<0.05 ;{ }^{* * *} p<0.01$.

At the peak of the impact, five days before the event, the estimated coefficient is 0.736 . The typical change in the lending fee in non-arbitrage transaction across events is $0.713 \%$. Thus, the mean impact of supply shock is to increase cumulated abnormal returns over 11 trading days by almost 52 bps. This a large yet quite credible magnitude. 
Table IXRobustness 1: Unweighted Instrumental Variables

\begin{tabular}{|c|c|c|c|c|c|}
\hline & \multicolumn{5}{|c|}{ Dependent variable: } \\
\hline & $\begin{array}{r}r_{\tau-15, \tau-5} \\
(1) \\
\end{array}$ & $\begin{array}{r}r_{\tau-10, \tau} \\
(2) \\
\end{array}$ & $\begin{array}{r}r_{\tau-5, \tau+5} \\
(3) \\
\end{array}$ & $\begin{array}{r}r_{\tau, \tau+10} \\
(4) \\
\end{array}$ & $\begin{array}{r}r_{\tau+5, \tau+15} \\
(5) \\
\end{array}$ \\
\hline Non-Arbitrage Delta fee & $\begin{array}{r}-0.190 \\
(0.468)\end{array}$ & $\begin{array}{c}0.013 \\
(0.390)\end{array}$ & $\begin{array}{c}0.727 \\
(1.051)\end{array}$ & $\begin{array}{c}0.341 \\
(0.964)\end{array}$ & $\begin{array}{c}0.201 \\
(1.317)\end{array}$ \\
\hline IoNE & $\begin{array}{c}-20.377 \\
(23.214)\end{array}$ & $\begin{array}{l}-4.653 \\
(38.028)\end{array}$ & $\begin{array}{r}-37.226 \\
(41.022)\end{array}$ & $\begin{array}{c}12.078 \\
(33.081)\end{array}$ & $\begin{array}{c}103.733^{* *} \\
(46.548)\end{array}$ \\
\hline Turnover & $\begin{array}{r}-0.840 \\
(1.286)\end{array}$ & $\begin{array}{c}-1.220 \\
(1.215)\end{array}$ & $\begin{array}{r}-2.193^{*} \\
(1.301)\end{array}$ & $\begin{array}{c}-2.950^{* * *} \\
(0.853)\end{array}$ & $\begin{array}{r}-1.511^{*} \\
(0.861)\end{array}$ \\
\hline Median Loan Fee & $\begin{array}{r}-0.144 \\
(0.199)\end{array}$ & $\begin{array}{c}0.160 \\
(0.230)\end{array}$ & $\begin{array}{c}0.410 \\
(0.286)\end{array}$ & $\begin{array}{c}0.333 \\
(0.259)\end{array}$ & $\begin{array}{c}0.122 \\
(0.335)\end{array}$ \\
\hline Constant & $\begin{array}{l}1.525^{* *} \\
(0.609)\end{array}$ & $\begin{array}{c}0.815 \\
(0.770)\end{array}$ & $\begin{array}{c}0.391 \\
(1.071)\end{array}$ & $\begin{array}{c}-0.046 \\
(0.964)\end{array}$ & $\begin{array}{c}-0.757 \\
(1.271)\end{array}$ \\
\hline Observations & 483 & 487 & 487 & 487 & 482 \\
\hline $\mathrm{R}^{2}$ & -0.001 & 0.007 & -0.031 & 0.016 & 0.056 \\
\hline Adjusted $\mathrm{R}^{2}$ & -0.009 & -0.001 & -0.040 & 0.008 & 0.048 \\
\hline
\end{tabular}

This table shows the estimates of equation 3. The depended variable is the cumulative returns. Delta Fee on Non-Arbitrage Transactions instrumented by the amount of short interest in arbitrage transactions and by delta fee in arbitrage transactions. Robust standard errors are clustered at the ticker level .

${ }^{*} p<0.1 ;{ }^{* *} p<0.05 ;{ }^{* * *} p<0.01$.

As a robustness check, we present results without weighting. Although the estimates does not change, the volatility increases and we loose significance.

\section{Conclusions}

We measure the causal impact of short-selling restrictions on returns by taking advantage of an unique dataset and an unique source of exogenous variation in rental fees. In Brazil during the 2010 - 2013 period rental transaction from individual investors to mutual funds carried an implicit tax discount 
on days of distribution of Interest on Net Equity (IoNE). The possibility of tax arbitrage produces an exogenous spike in rental fees and short interest during the days surrounding IoNE distribution, making it prohibitively expensive to short-sell for speculative reasons. Our data contains all rental transaction and the identity of the parts, thus allowing us identify transactions for tax arbitrage. We find that the variation of rental fees induced by the tax arbitrage operations has a large impact on abnormal returns, corroborating Miller's hypothesis. 


\section{References}

Boehmer, Ekkehart, Charles M. Jones, and Xiaoyan Zhang, 2013, Shackling short sellers: The 2008 shorting ban, The Review of Financial Studies 26, pp. 1363-1400.

Cohen, Lauren, Karl B. Diether, and Christopher J. Malloy, 2007, Supply and demand shifts in the shorting market, Journal of Finance 62, 2061-2096.

De-Losso, Rodrigo, Alan De Genaro, and Bruno C. Giovannetti, 2013, Testing the effects of short-selling restrictions on asset prices, Working papers, department of economics, University of Sao Paulo (FEA-USP).

Figlewski, Stephen, 1981, The informational effects of restrictions on short sales: Some empirical evidence, Journal of Financial and Quantitative Analysis 16, 463-476.

Kaplan, Steven N., Tobias J. Moskowitz, and Berk A. Sensoy, 2013, The effects of stock lending on security prices: An experiment, The Journal of Finance 68, pp. 1891-1936.

Miller, Edward M, 1977, Risk, uncertainty, and divergence of opinion, Journal of Finance 32, 1151-68.

Saffi, Pedro A. C., and Kari Sigurdsson, 2011, Price efficiency and short selling, Review of Financial Studies 24, 821-852. 